\title{
The lexical needs of ESP students in a professional field
}

\author{
Pam Peters ${ }^{\mathrm{a}, *}$, Trinidad Fernández ${ }^{\mathrm{b}}$ \\ ${ }^{a}$ Linguistics Department, Macquarie University, NSW 2109, Australia \\ ${ }^{\mathrm{b}}$ Departamento de Linguistica Aplicada a la Ciencia y a la Tecnologia, Univerisidad Politecnica de Madrid, Avda. de Juan de Herrera 6, 28040 Madrid, Spain
}

\section{A B S T R A C T}

This paper examines two kinds of questions relating to the lexical needs of professional ESP students:

(1) what range of terms and words do they need help with?

(2) what types of dictionary, bilingual and/or monolingual, can they make use of in

solving lexical problems?

The empirical data used in this study came from an in-class assignment with Spanish postgraduate students of architecture, showing that their lexical searches were less often for architectural terminology per se than for the shared terminology of science disciplines and academic discourse at large. In individual case studies, ESP students grappled with the special architectural senses of common English words, but were able to decode them with the help of both bilingual Spanish-English dictionaries and monolingual (English) dictio-naries, general and specialized whatever their L2 proficiency level. This finding runs counter to the commonly held belief that only advanced students are able to make use of monolingual (L2) dictionaries. Working with different types of dictionary engaged the students in critical lexicography, and in synthesizing lexical material from multiple sources to satisfy their lexical needs. Such training makes for independent language learning, pre-paring students for the bilingual or multilingual workplace.

Keywords:

ESP learners

L2 proficiency level

Lexical expansion

Architecture terminology

Bilingual dictionaries

Monolingual dictionaries

\section{Introduction: ESP students' lexical needs}

ESP students working within their professional field have very particular linguistic needs in their communities of practice, their discourses and types of documentation they use (Northcott \& Brown, 2006). These needs must be addressed as part of ensuring the transferability of ESP training to the workplace, as Dovey (2006) has argued. Apart from guaranteeing the disciplinary specificity of the teaching (Hyland, 2002), the approach should and can be strongly student-centred, in that it draws on the learners' professional engagement with the subject matter of the ESP course. This has been found to be a powerful motivator for L2 learners, for example in ESP training in the language of business (Dudley-Evans \& St. John, 1998). The students' long-term involvement with their specialized domain and their hopes of working in L2 environments (especially within Europe and Asia) give ESP a clear instrumental value. And since professional decisions and judgements hang upon their command of specialized language, there is a strong incentive for learners to grapple with the challenges of bridging the gap between their L1 and L2, and develop the necessary L2 lexicon.

\footnotetext{
* Corresponding author. Tel.: +612 98508773 ; fax: +61298509199.

E-mail addresses: pam.peters@mq.edu.au (P. Peters), Trinidad.fernandez@upm.es (T. Fernández).
} 
The learner's lexical needs are more easily benchmarked within a specialized field than in general language learning. In scientific domains, for example, physics (Kittredge \& Lehrberger, 1982), or within a professional domain such as architecture or statistics, the range of terms needed can be identified through their relative salience within the field, and their relative frequencies in computerized corpora of professional discourse (Peters et al., 2008). Related sets of terms can be clustered via larger and smaller scale ontologies or taxonomies, as a structured approach to the domain (Dicheva, 2008). Formal and multidimensional semantics can give ESP students access to dozens of related terms, for example, those used in specifying window designs through their shape, location, material, and direction of opening (Fernández \& Faber, 2011). Thus structured approaches to the lexicon, utilizing computer techniques and facilities, may be used to assist ESP students. They could, in future, be built into online dictionaries and lexical resources (Pimentel, L'Homme, \& Laneville, 2010), although they are difficult to accommodate in current print dictionaries.

Yet not all the terminology used in a discipline lends itself to schematic treatment, nor is it just the technical vocabulary of their discipline that ESP students need help with. They also have to deal with the 'semitechnical' or 'crossdisciplinary' terms shared with other pure and applied sciences (Halliday, 1988, p. 165), as well as the common academic vocabulary of tertiary education. This includes:

- semitechnical terms, for example, control, experiment, vector, and

- academic terms, for example, example, factor, solution.

These additional categories of terms support higher learning and knowledge, and are essential to ESP receptive language skills. Though the ESP student may encounter English semitechnical and academic terms in multiple contexts, their abstractness still contributes to the difficulty of reading specialized texts (Christie, 2002). Further problems for the ESP student are the fuzzy boundaries between technical and semitechnical terms, especially when they overlap with everyday usage, for example, footprint as used in environmental sustainability; and compound terms, for example, embodied energy, used in many science disciplines.

The central issue of this article is how to help ESP students acquire the lexical resources they need to deal with the discourse of their discipline. Specialized dictionaries (bilingual and monolingual) are an obvious resource for them to go to, yet few are designed for the full receptive needs of ESP students in a particular field. They rarely include general scientific (semitechnical) terms, or those from less formal registers of the specialized domain (Fernández, Flórez de la Colina, \& Peters, 2009, pp. 19-21). Nor do they embrace the near-equivalents used to paraphrase terms in cohesive chains, as illustrated by Rogers (2007, pp. 22-23) with the alternatives used for a noise suppressor, in English translations of a German text. To cover all their needs, ESP students, very likely, have to consult multiple dictionaries, although, like EFL students generally, they are unlikely to have had training in how to use those dictionaries (Chi, 2003).

This article considers first (in Section 2) how the different types of dictionaries could contribute to the lexical development of ESP students. In Section 3 the pedagogical, lexical and lexicographic issues are taken up in a research study conducted with postgraduate students of architecture at the Polytechnic University of Madrid (UPM). The findings of a multifaceted assignment in dictionary use are discussed in Sections 4 and 5, putting the spotlight on (i) the ESP students' lexical quests, and (ii) their experience in using dictionaries. Section 6 synthesizes the findings of the research in expanding the students' lexical and lexicographic repertoires.

\section{Dictionaries and their input to language learning}

\subsection{General dictionaries: monolingual, bilingual, bilingualized}

English dictionaries have diversified enormously since the 1970s. Native-speaker monolingual dictionaries have continually enlarged their scope so as to provide more multiword units and phraseologies, and a wider range of technical terms from emerging disciplines. Technical terms represent about 30\% of the headword list in desk-dictionaries (Landau, 2001, p. 34), ranging across all fields. Yet the general dictionary prioritizes technical terms where "lay and expert interests overlap", for example, trauma, quantum leap (Ahmad, Martin, Hölter, \& Rogers, 1995, p. 9), and its coverage is never as rich in any technical field as in specialized dictionaries. This sometimes means that the dictionary offers only a definition of what the term means in ordinary usage, rather than what it means to a subject expert within a specialized communicative setting (Pearson, 1998, p. 69). For all these reasons, the general dictionary can scarcely cover the full needs of the professional student in any given discipline.

The wider needs of foreign language learners have been recognized in recent decades by the major English dictionary publishers, including Cambridge University Press, Collins, Longman, Macmillan and Oxford University Press, with the publication of monolingual dictionaries specifically for L2 learners, designed to support their language development beyond the lexicon into grammar and collocation. These pedagogical developments in 'learners' dictionaries have impacted on the design of some bilingual dictionaries (e.g., Collins Robert French Dictionary (9th ed. 2010) with large quantities of supportive material added for L2 learners. Meanwhile the monolingual 'learners' dictionary has, in some cases, been 'bilingualized', as in the Oxford Advanced Learners English-Chinese Dictionary (2004) and the Longman Dictionary of Contemporary English: Chinese edition (2004). Both dictionaries provide Chinese translations of most components of the microstructure, to support 
lower proficiency learners in their L1 (Cowie, 1999, pp. 193-194) while immersing them in the L2. Yet making space within the dictionary microstructure for the bilingualized text, along with extra grammatical and collocational information to aid the L2 learner, reduces the overall number of headwords in the macrostructure (Warsch, 2005). The bilingualized learners' dictionary is thus prevented from expanding its coverage of technical terms, which limits its value for ESP lexical development.

\subsection{Specialized dictionaries}

Publishing economics work against the production of separate dictionaries for the native-speaker and language-learner in specialized fields. Instead, the specialized dictionary (monolingual or bilingual) serves readers with both kinds of language background, ranging from expert practitioners to students in the discipline (Fuertes-Olivera \& Arribas-Bano, 2008). Most technical and terminological dictionaries are designed to support translation rather than wider language learning, and do not supply definitions or details of grammar and collocation to enrich the user's lexical understanding. The very few specialized bilingual dictionaries designed specifically for $L 2$ learners have been published in high-demand commercial fields such as business; for example, the bilingual dictionaries by Alcaráz, Hughes, and Campos Pardillos (1999) Diccionario de términos de marketing, Inglés-Español, Spanish-English; and Alcaráz and Hughes (2008) Diccionario de Términos Económicos, Financieros y Comerciales. More recently a dynamic online bilingual English-Spanish learners' dictionary has been developed in the domain of accounting (El Diccionario Inglés-Español de Contabilidad, 2012). Being online it has unlimited space in which to support L2 language learning while providing a large specialized vocabulary. There are no equivalents in the applied or social sciences.

Specialized dictionaries (online or not) are still challenged as to how far their coverage should go beyond the core terminology of a particular discipline. This stems from the fuzzy boundary between technical and semitechnical vocabulary noted in Section 1. It also reflects the controversy between prescriptive and descriptive terminologists, and the fact that many of the terms in expanding fields of science and social science are applications of polysemous words, not the monosemous terms on which terminology has traditionally focused (Temmerman, 2000). Technical terms are often particular senses of general words, raising considerable challenges as to how to present them in specialized dictionaries. The dividing line between specialized and general senses is not easily drawn, especially when both are present in interdisciplinary fields such as architecture (Fernández et al., 2009), witness examples like beam and load. When listed as translation equivalents in bilingual dictionaries, they can suggest a higher level of isomorphism between the two languages than is actually the case. Typically there is only partial equivalence (Fuertes-Olivera \& Arribas-Bano, 2008). The spectrum of terminology to be embraced is thus an issue for specialized lexicography as well as for ESP pedagogy.

\subsection{Empirical research on dictionary use}

Educational research on dictionaries has established their potential in L1 and especially L2 language learning (Welker, 2010), and their support for developing competence (receptive and/or productive skills). The contribution of dictionaries to language learning is, however, difficult to research because of all the contextual factors affecting the user and their dictionary usage (Tarp, 2009, pp. 279-280). The 320 dictionary-focused studies included in Welker's chronological overview show great diversity in the users, tasks, and types of dictionary involved, and the comparability of their findings should never be taken for granted (Lew, 2002). Yet experimental studies on L2 learners' use of different types of dictionary have repeatedly confirmed the language-beginner's reliance on bilingual dictionaries for essential look-up purposes (Bogaards, 2005), and the greater ability of advanced language learners to use monolingual dictionaries, as in Lew (2004).

Research on the use of specialized dictionaries in ESP education is rare - conspicuous by its absence in Welker's (2010) survey, apart from an early (1983) study on the use of a 'technical' dictionary, based on sketchy, second-hand information. That apart, many studies of EFL dictionary use are unsatisfactory from the ESP perspective because they create artificial dictionary tasks for the participants, and lack ecological validity in terms of ESP lexical acquisition and the dictionary consultation process.

One other user-related factor affecting dictionary use is the learner's level of proficiency in L2, found in only a few of the most recent studies reported by Welker (2010). Two others published since (Chen, 2011; Tono, 2011), show how language proficiency is a differential in EFL students' use of dictionary material. Yet the impact of differing proficiency levels on dictionary use by ESP students remains under-researched. It is possible that their professional domain knowledge compensates, to some extent, for lower general-language proficiency (Fernández et al., 2009) in their acquisition of the L2 specialized lexicon.

The lack of training in dictionary use for L2 students has emerged in research studies from Herbst and Stein (1987) to Lew and Galas (2008). Two rather different types of training are noted by Welker (2010, p. 9):

(i) teaching dictionary skills, that is, extracting information from the complex microstructure of the dictionary, and

(ii) critical comparison and review of dictionaries, in terms of their overall content.

The second arena for training Welker sets aside as being the work of experts rather than empirical research into dictionary use: "research on dictionaries is only empirical if users are involved in some way (asked, observed or tested)" (p. 9). Yet a large-scale study of dictionary ratings by EFL school students in Poland (Lew, 2004) provides statistically significant confirmation of their generic preference for the bilingual dictionary, as well as the interaction of their ratings with L2 proficiency 
levels. ESP students can likewise be asked to evaluate the various dictionaries they consult to satisfy their lexical needs as specialists and as L2 language learners. They are well positioned to compare the utility of different types of dictionary and engage in "critical lexicography" (Peters, Tent, \& Fernández, 2006) as part of their ESP education.

This is the type of embedded training and inquiry into dictionary use put to empirical investigation in the research reported below. It takes as its starting point the broader lexical needs of ESP architecture students, asking them to identify their own needs, make independent dictionary choices, and reflect on the development of their professional vocabulary.

\section{Empirical investigation of dictionary use by ESP students in architecture}

\subsection{Overall aim}

The overall aim of the study was to investigate the interplay between dictionary use and the acquisition of specialised vocabulary by ESP students in postgraduate education. More specific aims and research questions were:

- to profile the terms/and words needed by postgraduate ESP students in architecture. (Do they mostly look up technical terms, or a wider range of scientific and academic words?)

- to review the types of dictionaries used by postgraduate ESP students of differing proficiencies. (Are lower proficiency ESP students only able to use bilingual dictionaries?)

- to evaluate the effectiveness of an assignment focusing on specialized vocabulary and the use of dictionaries, in developing the ESP student's lexical and lexicographic repertoires. (Did it achieve its purpose?)

\subsection{Methods and participants}

\subsubsection{Methods}

Complementary methods (quantitative and qualitative) were used to triangulate both the lexical and lexicographical issues under investigation. The known disadvantages of questionnaires were offset by the use of closed and open questions, as well as naturalistic case studies with protocol analysis (Lew, 2002; Lew, 2011). The research was conducted with a large group of postgraduate students, whose English-language proficiencies were known (see Section 3.2.2) and whose previous use of dictionaries was ascertained through self-reporting in a preliminary survey (Section 3.2.3). Their lexical needs and ability to use dictionaries were examined through a two-part assignment, discussed in Sections 4 and 5.1-5.2. A post-assignment questionnaire was distributed, to distil the students' further reflections on the use of dictionaries, reported in Section 5.3.

\subsubsection{Participants and their $L 2$ proficiency}

This study was carried out with a class of 110 postgraduate Spanish-speaking architecture students in the Building Engineering School of the Polytechnic University of Madrid (UPM). The students were drawn from various background disciplines, architectural design, construction, quantity surveying and so forth, with varying levels of English language proficiency according to the Common European Framework of Languages for Reference (CEFR) and other testing systems, as shown in Table 1.

Table 1

Proficiency levels among the students, assessed with CEFR Quick Placement Test.

\begin{tabular}{|l|c|c|c|c|c|}
\hline \multicolumn{1}{|c|}{ User } & $\begin{array}{c}\text { ALTE* } \\
\text { Level }\end{array}$ & $\begin{array}{c}\text { Cambridge ESOL } \\
\text { Examinations }\end{array}$ & $\begin{array}{c}\text { Common } \\
\text { European } \\
\text { Framework } \\
\text { (CEFR) level }\end{array}$ & $\begin{array}{c}\text { No. of } \\
\text { students at } \\
\text { each level } \\
(\mathbf{n}=\mathbf{1 1 0})\end{array}$ & $\begin{array}{c}\% \text { of } \\
\text { students at } \\
\text { each level }\end{array}$ \\
\hline Proficient & 5 & $\begin{array}{c}\text { Cambridge } \\
\text { Proficiency (CPE) }\end{array}$ & $\mathrm{C} 2$ & 1 & $1 \%$ \\
\hline Proficient & 4 & $\begin{array}{c}\text { Cambridge } \\
\text { Advanced (CAE) }\end{array}$ & $\mathrm{C} 1$ & 11 & $10 \%$ \\
\hline Independent & 3 & $\begin{array}{c}\text { First Certificate } \\
\text { (FCE) }\end{array}$ & B2 & 39 & $35 \%$ \\
\hline Independent & 2 & $\begin{array}{c}\text { Preliminary English } \\
\text { Test (PET) }\end{array}$ & B1 & 43 & $39 \%$ \\
\hline Basic & 1 & $\begin{array}{c}\text { Key English Test } \\
\text { (KEY) }\end{array}$ & $\mathrm{A} 2$ & 15 & $14 \%$ \\
\hline Basic & 0.5 & A1 & 1 & $1 \%$ \\
\hline
\end{tabular}

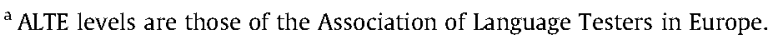


Table 1 shows that the range of L2 proficiency within the class was close to a standard distribution, confirming that they form a balanced sample. About $15 \%$ of students were at the lowest level of English proficiency (A1 and A2 levels of the European Framework), and a large group (39\%) fell into the lower mid-bracket (B1). They were balanced by the $46 \%$ in the B2 and $\mathrm{C}$ brackets. So the experimental findings reported below represent the responses of a wide range of postgraduate ESP students to the challenges of extracting lexical information from dictionaries.

\subsubsection{Students' previous use of dictionaries}

A questionnaire asking students about their use of dictionaries (see Appendix 1) was distributed at the start of semester to all students, to establish a baseline for the study. Students were asked what types of dictionaries they used, whether they had any training in dictionary use, and what items they tended to look for in them. Selected results from the questionnaire for each English-language proficiency level are shown Table 2. The unbracketed percentages are to be read horizontally as proportions of the actual number (bolded) responding to each question. The bracketed percentages in the far column represent the proportion of the whole cohort responding to each question.

The responses to Q1 in Table 2 confirm that the great majority of the Spanish ESP students (all but one at the highest proficiency level) use bilingual dictionaries - the first port of call for language learners, as noted in Section 2.3. At least half of the students (55\%) across the mid-proficiency range A2 to $\mathrm{C} 1$, reported using larger bilingual dictionaries (not just pocket-sized ones). A smaller proportion (36\%) used monolingual English learners' dictionaries, mostly in the B and C proficiency levels. Few students $(11 \%)$ had ever used bilingualized English to Spanish dictionaries, correlating with their limited availability (Sections 2.1-2.2). The largely negative findings on dictionary training (Q3) are in line with those found elsewhere in the world (e.g., Chi, 2003): only $20 \%$ of the students had ever been instructed in the use of dictionaries. Some said they knew that their difficulty in finding explanations of L2 architectural words and terms might be because they had not chosen the appropriate dictionary - thus flagging the need for training in dictionary discrimination (cf. Section 2.3).

While Q1 and Q3 can be considered questions of fact (Welker, 2010, pp. 12-13), Q2 and Q4 are ones that call for more generic thinking about dictionary use, representing perceptions rather than actual use (Tarp, 2009, pp. 284-285). The students are, however, responding in the context of ESP training, and the differential percentages for Q2 on the translational directions for which they use dictionaries (88\% for English to Spanish, $72 \%$ for Spanish to English) are broadly in line with the primary and secondary activities of their course, and show little differentiation across the L2 proficiency range. Q4 invokes a set of lexical categories with fuzzy boundaries (discussed in Sections 1 and 4), so the results are subject to individual interpretation, especially for the term 'semitechnical'. This might explain why only about half $(54 \%)$ agreed they looked them up in the dictionary. The majority of students at all L2 proficiency levels (80\%) believed that they looked up technical terms, which are of course highly salient in architectural discourse. However further investigation (below) of the terms actually looked up by the students presents a different lexical profile.

\section{Assignment Findings Part 1: Terms and words sought by ESP students}

The first part of the class assignment asked students to identify at least 20 words from their architectural reading which were 'unfamiliar' or 'new' enough to take them to a dictionary. We hypothesized that the vocabularies they would look up might include more than terms unique to architecture because of its interdisciplinarity (Fernández \& Peters, 2009). That apart, postgraduate ESP students in Madrid cannot be assumed to have encountered common English vocabulary for scientific and academic concepts during undergraduate studies in Spanish. The applications of such terms in architectural discourse might be just as unfamiliar as terms particular to architecture.

The lexical data from a sample of 20 class assignments was analysed for its composition. It included more than 430 words, with some duplications, making a total of 360 different words and terms. The terms/words identified by the students were then classified into three broad categories:

- Type A: terms specific to architecture and building systems: cladding, duct, insulation, lintel.

- Type B: terms for concepts common to scientific and other academic disciplines: benefit, porous, resources, stress, and

- Type C: ordinary words for raw materials, everyday phenomena: crack, lump, measure, straw.

The boundaries between the more and less technical types are not necessarily clear cut (Chung \& Nation, 2003), yet Types $A$ and $C$ provide a scale between the narrow technicality of terms at one end and the much greater polysemy of words at the other.

In order to profile the terms, words and compounds most needed by Spanish architecture students, we focused first on the 54 items identified by at least two students as 'unfamiliar'. Terms looked up by more than two students are marked with an $\mathrm{x}$-numeral in brackets. 
Table 2

Results of preliminary survey on students' use of dictionaries.

\begin{tabular}{|c|c|c|c|c|c|c|c|c|c|c|c|c|c|}
\hline & ST & DEl & $S^{\prime}$ & FR & vels & & & & & & & & \\
\hline & A1 & A1 & A2 & A2 & B1 & B1 & B2 & B2 & C1 & C1 & $\mathrm{C} 2$ & $\mathrm{C} 2$ & \multirow{2}{*}{$\begin{array}{c}\text { Total } \\
\text { no. } \\
\%\end{array}$} \\
\hline QUESTIONS & no. & $\%$ & no. & $\%$ & no. & $\%$ & no. & $\%$ & no. & $\%$ & no. & $\%$ & \\
\hline No. of students & 1 & $1 \%$ & 15 & $14 \%$ & 43 & $39 \%$ & 39 & $35 \%$ & 11 & $10 \%$ & 1 & $1 \%$ & 110 \\
\hline \multicolumn{14}{|l|}{$\begin{array}{l}\text { 1. Which type of } \\
\text { dictionary do you } \\
\text { use? }\end{array}$} \\
\hline $\begin{array}{l}\text { bilingual } \\
\mathrm{E}>\mathrm{Sp} / \mathrm{Sp}>\mathrm{E}\end{array}$ & 1 & $1 \%$ & 15 & $14 \%$ & 42 & $40 \%$ & 36 & $34 \%$ & 11 & $10 \%$ & 0 & $0 \%$ & $105(95 \%)$ \\
\hline ...smaller & 1 & $2 \%$ & 11 & $25 \%$ & 18 & $41 \%$ & 11 & $25 \%$ & 3 & $7 \%$ & 0 & $0 \%$ & $44(40 \%)$ \\
\hline ...larger & 0 & $0 \%$ & 4 & $7 \%$ & 24 & $39 \%$ & 25 & $41 \%$ & 8 & $13 \%$ & 0 & $0 \%$ & $61(55 \%)$ \\
\hline $\begin{array}{l}\text { monolingual } \\
\text { English: }\end{array}$ & 0 & $0 \%$ & 3 & $8 \%$ & 16 & $40 \%$ & 12 & $30 \%$ & 8 & $20 \%$ & 1 & $3 \%$ & $40 \quad(36 \%)$ \\
\hline ...smaller & 0 & $0 \%$ & 1 & $8 \%$ & 6 & $46 \%$ & 5 & $38 \%$ & 1 & $8 \%$ & 0 & $0 \%$ & $13(12 \%)$ \\
\hline ...larger & 0 & $0 \%$ & 2 & $7 \%$ & 10 & $37 \%$ & 7 & $26 \%$ & 7 & $26 \%$ & 1 & $4 \%$ & $27(24 \%)$ \\
\hline $\begin{array}{l}\text { bilingualized } \\
\text { E>Sp }\end{array}$ & 0 & $0 \%$ & 1 & $8 \%$ & 4 & $33 \%$ & 6 & $50 \%$ & 1 & $8 \%$ & 0 & $0 \%$ & $12(11 \%)$ \\
\hline \multirow{2}{*}{\multicolumn{14}{|c|}{$\begin{array}{l}\text { 2. Do you use } \\
\text { dictionaries to } \\
\text { translate... }\end{array}$}} \\
\hline & & & & & & & & & & & & & \\
\hline$\ldots . \mathrm{E}>\mathrm{Sp} ?$ & I & $1 \%$ & 14 & $14 \%$ & 38 & $39 \%$ & 34 & $35 \%$ & 10 & $10 \%$ & 0 & $0 \%$ & $97(88 \%)$ \\
\hline$\ldots$. Sp>Eng? & 1 & $1 \%$ & 12 & $15 \%$ & 33 & $42 \%$ & 27 & $34 \%$ & 6 & $8 \%$ & 0 & $0 \%$ & $79(72 \%)$ \\
\hline \multicolumn{14}{|l|}{$\begin{array}{l}\text { 3. Have you ever } \\
\text { had dictionary } \\
\text { training? }\end{array}$} \\
\hline $\mathrm{Y}$ & 0 & $0 \%$ & 2 & $9 \%$ & 9 & $41 \%$ & 10 & $45 \%$ & 1 & $5 \%$ & 0 & $0 \%$ & $22(20 \%)$ \\
\hline $\mathrm{N}$ & 1 & $1 \%$ & 12 & $14 \%$ & 33 & $38 \%$ & 29 & $34 \%$ & 10 & $12 \%$ & 1 & $1 \%$ & $86(78 \%)$ \\
\hline \multicolumn{14}{|l|}{$\begin{array}{l}\text { 4. Do you mostly } \\
\text { look up ... }\end{array}$} \\
\hline ... technical terms? & 1 & $1 \%$ & 11 & $13 \%$ & 36 & $41 \%$ & 28 & $32 \%$ & 11 & $13 \%$ & 1 & $1 \%$ & $88(80 \%)$ \\
\hline $\begin{array}{l}\text {...semitechnical } \\
\text { terms? }\end{array}$ & 1 & $2 \%$ & 5 & $8 \%$ & 23 & $38 \%$ & 23 & $38 \%$ & 8 & $13 \%$ & 0 & $0 \%$ & $60(54 \%)$ \\
\hline ...ordinary words? & 0 & $0 \%$ & 9 & $15 \%$ & 29 & $48 \%$ & 18 & $30 \%$ & 4 & $7 \%$ & 0 & $0 \%$ & $60 \quad(54 \%)$ \\
\hline
\end{tabular}




\begin{tabular}{|c|c|}
\hline Type A & $\begin{array}{l}\text { beam - blind - building - cladding - facade - grout } \\
\text { - gutter - heating - insulation - refurbishment - } \\
\text { rubble - slab - timber }\end{array}$ \\
\hline Type B & $\begin{array}{l}\text { assessment - attachment - benefit }- \text { construction }(\mathrm{x}-3) \\
\text { consumption }(\mathrm{x}-5) \text { - contractor - development - embedded }(\mathrm{x}-3)- \\
\text { embodied_energy - energy }(\mathrm{x}-3)-\text { environment }(\mathrm{x}-3)- \\
\text { framework }(\mathrm{x} 3)-\text { hazardous - impact - leakage - } \\
\text { load - moisture }(\mathrm{x}-3)-\text { production - raw_material - recycling - } \\
\text { reduction - resources - shortage - shrinkage - sludge - } \\
\text { storage - stress - sustainability }(\mathrm{x}-3)-\text { tailored - waste }(\mathrm{x}-7)\end{array}$ \\
\hline Type C & $\begin{array}{l}\operatorname{clay}(\mathrm{x}-5)-\operatorname{coal}(\mathrm{x}-3)-\operatorname{crack}(\mathrm{x}-3)-\text { lime }- \text { management }(\mathrm{x}-3)- \\
\text { measure - pump - rubber - straw - tailored - thickness }\end{array}$ \\
\hline
\end{tabular}

Table 3 shows that far more Type B words (academic and shared scientific vocabulary) were looked up than either Types A or C; more than twice the number. These findings clearly contrast with the results of Q4 in Table 2, where the students (self)-reported that their lexical quests were most often for 'technical'/Type A words. Yet Type B words such as consumption, environment, framework, waste are clearly more abstract than either of the other types, which helps to explain their difficulty (Christie, 2002). Their applications in architecture are not to be taken for granted. They are also typically Latin-derived, and thus apparently closer to the Spanish vocabulary - though they also present the 'false friends', of which students might be aware. Students need help more often with the general scientific and academic vocabulary than the specifically architectural terms - even though the total inventory of architectural terms would be much larger.

In fact, the proportions of the three types of vocabulary looked up remained much the same, when we took in the whole set of 360 different terms identified by the student sample as 'unfamiliar'. The percentages are shown in Table 4.

A chi-square test found no significant difference between the two data sets ( $p$-value $=0.222$ ), confirming that the ESP postgraduates' lexical needs are proportionally greater among abstract scientific and academic words than the technical terms of architecture. Some of the architectural terms might be familiar from architectural practice in their L1, and not so difficult to acquire as the $\mathrm{L} 2$ equivalent for something visible or tangible. The applications of abstract L2 concepts present the biggest barriers to understanding in ESP education, and there students most naturally turn to dictionaries for help. But which dictionaries?

Table 4

Numbers of terms of each type identified by students as "unfamiliar".

\begin{tabular}{|l|l|l|l|}
\hline & Type A & Type B & Type C \\
\hline $\begin{array}{l}\text { Terms unfamiliar to more than one } \\
\text { student }(\mathrm{n}=54)\end{array}$ & 13 & 30 & 11 \\
\hline $\begin{array}{l}\text { Total set of different terms noted } \\
\text { as unfamiliar by students }(\mathrm{n}=360)\end{array}$ & 106 & 155 & 99 \\
\hline
\end{tabular}




\section{Assignment Findings Part 2: Dictionary use by ESP students}

\subsection{Assignment task}

In the second part of the dictionary assignment, students were set the task of following up six of the terms/words they had identified as 'unfamiliar', and investigating their exact meaning in context, with the aim of making them part of their professional vocabulary. They were encouraged to use both bilingual and monolingual dictionaries, general and/or specialized, at their discretion. The only advice was that they choose the most recent editions. They were asked to write an account (in English, with Spanish paraphrasing where necessary) of their quest for the meaning and usage of six terms, indicating what and where the dictionaries had contributed. Excerpts from six such accounts are presented in Section 5.2, two at each proficiency level. Following the assignment, all students were asked to respond to a survey on their views of dictionaries, dictionary use and the need for training (Section 5.3).

\subsection{Dictionary use: Case studies at three levels of proficiency}

The students' written accounts of how they used dictionaries in understanding architectural vocabulary served us as semi-structured protocols (Tarp, 2009, p. 287). They provided qualitative data on individual lexical issues and the relevant information extracted from dictionaries they consulted. In summary form, the six cases reported below also serve to differentiate the investigative process for students at the three proficiency levels.

Low proficiency (A) level students: selected lookup queries:

- rebar [context: 'degree of rebar corrosion'] For this highly specialized term, the student first looked up a bilingual SpanishEnglish/English-Spanish dictionary (Diccionario politécnico de las lenguas española e inglesa, 2009), which simply gave the same word rebar as the Spanish translation equivalent. The student did not find the meaning of rebar till he searched in a monolingual dictionary (McGraw Hill's Dictionary of Architecture and Construction (3rd ed., 2006) which provided him with a definition: "steel bar having ribs to provide greater bonding strength when used as a reinforcing bar in reinforced concrete". This L2 explanation gave him what he needed to understand the concept attached to an otherwise opaque term in English and Spanish.

- filling [context: 'earthwork support filling to excavations'] The grammatical ambiguity of this English word (as adjective and noun) made for two sets of translation equivalents (llenado, relleno) in a bilingual dictionary, and the student was unable to find the architectural meaning among them. He then consulted a monolingual specialized dictionary (the Penguin Dictionary of Building, 2004) to find the relevant senses of filling as a noun used in architecture.

Although the first choice of these and other low proficiency students (see Table 2 Q1) was the bilingual dictionary, they discovered its limited coverage of architectural terms, and went to specialized L2 dictionaries to understand how each term was used. None of the C-level students had used an English monolingual dictionary before. But when motivated by the assignment - and helped by their professional knowledge of architecture - they discovered they could understand enough of the information provided in the $\mathrm{L} 2$ specialized dictionary to decode the term. The fact that specialized dictionaries are "knowledge-orientated" (Bergenholz \& Tarp, 2003) is a plus in this regard.

Intermediate proficiency (B) level students: selected lookup queries:

- clay [context: related to bricks] was the unfamiliar everyday word for an intermediate-level student who had only ever used bilingual dictionaries. He found that by looking it up in a monolingual (L2) general dictionary he was able to understand the meaning/concept through the description: a "heavy sticky earth". He then went back to the bilingual dictionary to be sure of the translation equivalent in Spanish, working between monolingual and bilingual dictionaries to confirm his understanding.

- demise [context: "when a structure is built out to its demise"] The student had difficulty (not unsurprisingly) with the architectural use of this rather formal word from the Journal of the Royal Institute of British Architects, and could find no adequate translation equivalent in a bilingual dictionary. He then sought to decode the contextual meaning by referring to monolingual (L2) general and specialized dictionaries. Using information extracted from them, he could paraphrase the expression in his L1: cuando se ejecuta una estructura sin posibilidad de ampliación ("when a structure is built out to its ultimate extension"). The student's knowledge of the architectural issue helped to translate the word in the larger context.

Intermediate students like these move more confidently between bilingual and monolingual (L2) dictionaries and back again, recognising the value of each. The monolingual (L2) dictionary becomes their primary aid in scoping the meaning of the term, which can then be checked by recourse to the bilingual dictionary or a paraphrase in their L1.

Advanced proficiency (C) level students: selected lookup queries: 
- jacket [context: "steel jacket to upgrade corrosion-damaged reinforced concrete columns"] This everyday word is highly polysemous in English, and even as an architectural term has two slightly different meanings. In the Dictionary of Architecture and Construction (3rd ed. 2006), the student found the following definitions:

Jacket: 1. A metal or cloth covering over the heat insulation which is applied to exposed heating pipes and ducts. 2. An outer casing around a pipe or vessel, the space between being filled with a fluid for cooling, heating, or maintaining a fixed temperature.

The Spanish translation equivalent for jacket in these senses - funda - is also polysemous, and challenged the student with its other applications ranging from "case", "cover", "sleeve" to "sheath" and "holdall" that is, "small bag". The polysemy of words within one's L1 has been found to make greater difficulties for translators than in the L2 (Tsakona, 2007, pp. 9-10), and "funda" as a translation equivalent for jacket exemplifies the problem. The student commented: "I hadn't used a specialized dictionary before, but I think for a specialized context it is fundamental to clarify the meaning of words. [...] If we use together monolingual and bilingual dictionaries we can use the words correctly, because we are sure of the meaning of the word". The double polysemy involved here was resolved by the student's ability to make use of extended L2 definitions, helped by his domain knowledge. From his remarks it is also clear that he is moving on from the immediate task of decoding terminology to encoding, as in the comment that through using both types of dictionary: "We know the collocations ...learn if it is a noun, adjective, etc... the different contexts where it can be used".

- run-down [context "when faced with run-down buildings, imaginative architects can prove their worth..."] Here the student was challenged by a set of alternative senses for run-down in a bilingual dictionary: Harper Collins Spanish-English/ English Spanish dictionary, 2000. They included [building] descuidado, mal cuidado; [battery] agotado; [health] debilitado; [organization] en decadencia. The student did not find the exact meaning in any of the fields provided, though he could guess the essential meaning from the translation equivalents provided for the different applications. He then searched in a monolingual dictionary, Collins COBUILD Advanced Learner's English Dictionary (4th ed. 2003), where the explanation: "A run-down building or area: when it is in very poor condition", confirmed his understanding. Through this process he reached his own translation: [edificio] ruinoso.

The terminological problems tackled by these advanced-level students involve words with considerable polysemy in L1 and/or L2 - words which were known to them but not in their architectural senses. The students responded to the semantic challenges, using their greater command of English and the domain knowledge they could draw on, to find lexical answers that satisfied them. Their approach is summed up by another advanced-level student:

In my case, the best way to find out the meaning of a word is to look up a word in a monolingual dictionary, understand the meaning, and then look it up in a bilingual dictionary to be sure if my guess about the translation equivalent is the same as the one given.

With these advanced-level students, we find the clearest strategy for combining information from monolingual and bilingual dictionaries in understanding previously unfamiliar terms.

\subsection{Findings from post-assignment survey on dictionary experience}

The protocols of the preceding Section (5.2) showed that students at all three L2 proficiency levels were able to make use of multiple dictionaries, both bilingual and monolingual, for their assignment. They were then asked by means of a simple questionnaire (see Appendix 2) to summarize their experience of using different dictionaries, and their perceived need for dictionary training. The results in relation to L2 proficiency levels are shown in Table 5 (those for students in proficiency levels $\mathrm{A} 1$ and 2 , and $\mathrm{C} 1$ and 2, have been pooled because of the small numbers). The students' responses (raw numbers and percentages) are to be read vertically within the four sections for each proficiency group.

Table 5 shows that students all across the L2 proficiency range (87\%) accept that dictionaries differ in their content (Q1). This entails the need to use more than one dictionary in solving lexical problems (Q2), as recognized by a large majority (79\%), and articulated in the case studies of Section 5.2. The students' responses to QQ 1 and 2 complement each other, synthesizing their experience of dictionary consultation, and showing that the underlying purpose of the assignment, as embedded dictionary training, was achieved for most students. Q3 focused on understanding architecture terms in their natural contexts, given that L2 students can, to some extent, predict or guess the meanings of unfamiliar words in situ while reading (Nuttall, 1982), rather than resorting to a dictionary. Their ability to do so clearly correlates with L2 proficiency. About two thirds of A and B1 proficiency level students disagree with the proposition that you can usually understand architectural terms in context without going to a dictionary, whereas the majority of $C$ proficiency level students agree with the proposition. B2 level proficiency students are the transitional group, with $46 \%$ showing lessened dependency on dictionaries. The correlation with general language proficiency here is as might be expected, since more sustained comprehension of the written text enriches the contexts for understanding new terms and words in the overall web of meaning.

The students' responses to Q4 on dictionary training are equivocal, due to the openness of the question. It could be taken to refer to standalone dictionary training, or the embedded training in the use of dictionaries which they had already experienced through the assignment. Either interpretation would correlate with the fact that only $46 \%$ of the cohort agreed that 
Table 5

Students' overall comments on their experience of using dictionaries.

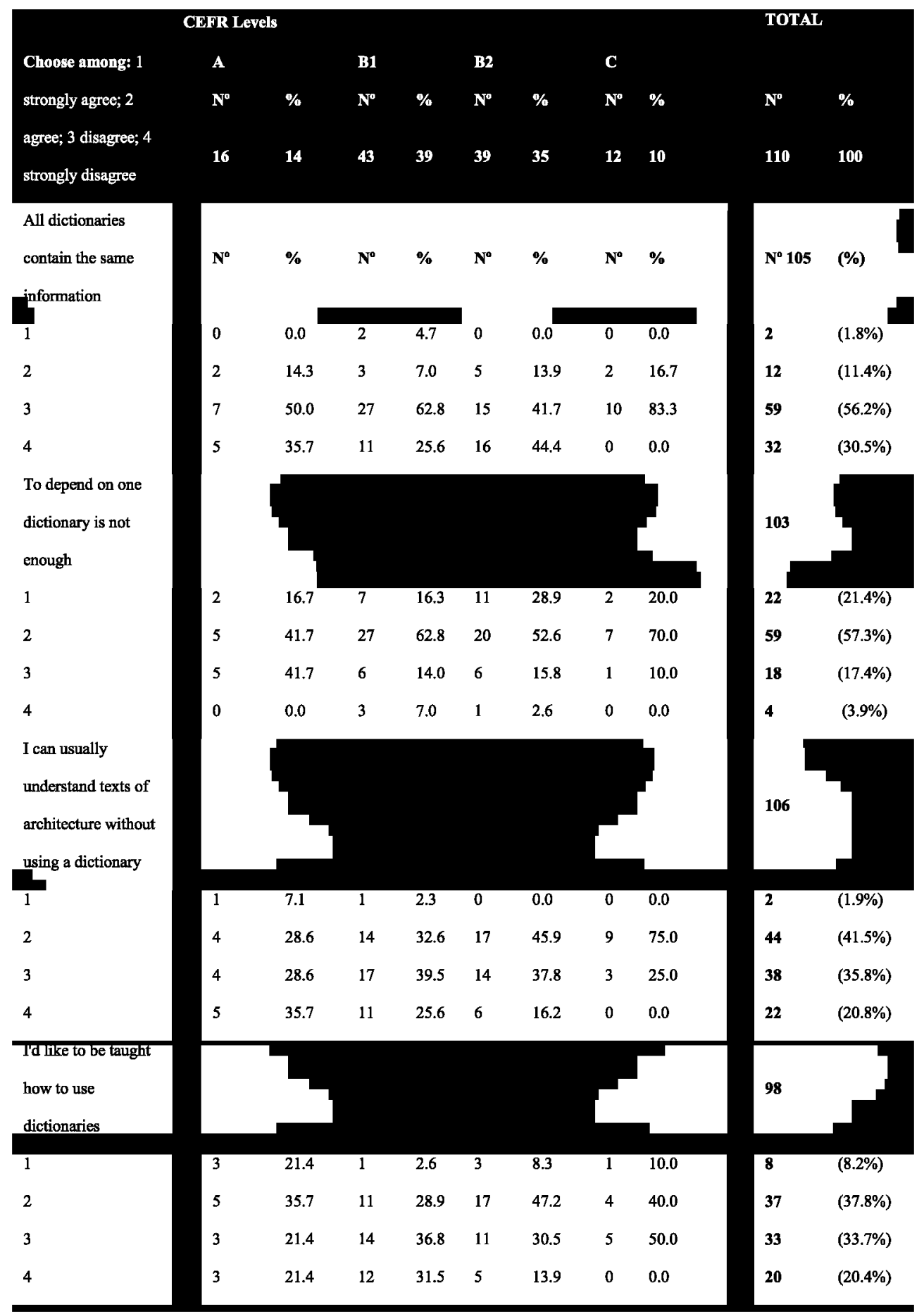

they wanted more dictionary training. The negative response was most pronounced among B1 proficiency level students (68\%), whereas those on either side (A and B2) were slightly positive. The low level of enthusiasm for dictionary training 
shown by the B1 proficiency students finds a possible parallel in Lew's (2004) research on EFL students' ratings of their mostused dictionaries, where the least positive ratings were returned by students in the lower mid-proficiency range. But the mixed response overall would also correlate with the students feeling they had learned through the assignment how to make productive use of dictionaries, as shown in the individual cases analysed in Section 5.2. The students' responses to Q1 and Q2 reflect understanding of the lexicographic fundamentals, and the value of combining information from multiple dictionaries to solve individual lexical problems. The need for formal training on using dictionaries is then less critical. With ESP students, it can be taught as a professional language-learning strategy, amid exposure to professional discourse.

\section{Summary findings and conclusions}

The dictionary assignment tested with Spanish ESP architecture students served to identify the different kinds of vocabulary they need, and to demonstrate the gains of their consulting multiple dictionaries to solve lexical problems. The lexical analysis of Section 4 showed that ESP students in architecture are less often challenged by its technical terminology than by the common scientific and academic vocabularies of higher education - well beyond those of the standard academic wordlists (Read \& Ambrose, 1999). Architectural uses of everyday words such as filling and jacket also presented challenges across the $\mathrm{L} 2$ proficiency range.

The protocol analysis of Section 5.2 showed that even lower proficiency students can make use of monolingual (L2) dictionaries in satisfying their quests for lexical meaning, though they are still inclined to go first to bilingual dictionaries. A small amount of contextualized dictionary training helps to support independent language learning among ESP students, as preparation for the workplace (Dovey, 2006), and demonstrates the value of teaching postgraduate students to become critical users of dictionaries (Peters \& Tent, 2006). The dictionary assignment described in this article would work equally well in other domains of ESP, where the students' professional knowledge provides support and incentives for language learning. It confirms the value of the ESP approach generally, that is, making the disciplinary focus very specific (Hyland, 2002).

While new types of bilingualized, specialized and encyclopedic dictionaries continue to evolve for ESP learners in the unlimited space online (Fuertes-Olivera, 2010), this research shows that postgraduate ESP students can make effective use of existing bilingual and monolingual dictionaries for their lexical needs.

\section{Appendix A. Supplementary material}

Supplementary data associated with this article can be found, in the online version, at http://dx.doi.org/10.1016/ j.esp.2013.05.002.

\section{References}

Ahmad, K. W., Martin, W., Hölter, M., \& Rogers, M. (1995). Specialist terms in general language dictionaries. University of Surrey AI Technical Report CS-95-14. Retrieved from. http://www.mcs.surrey.ac.uk.

Bergenholz, H., \& Tarp, S. (2003). Two opposing theories: On H.E. Wiegand's recent discovery of lexicographic functions. Hermes, Journal of Linguistics, 31 , $171-196$.

Bogaards, P. (2005). Dictionaries and productive tasks in a foreign language. Kernerman Dictionary News No.13. Retrieved from. kdictionaries.com.

Chen, Y. (2011). Studies on bilingualized dictionaries: The user perspective. International Joumal of Lexicography, 24(2), 161-197.

Chi, M. -L. A. (2003). An empirical study of the efficacy of integrating the teaching of dictionary use into a tertiary English curriculum in Hong Kong. Language Centre: Hong Kong University of Science and Technology: Hong Kong.

Christie, F. (2002). The development of abstraction in adolescents. In M. Schleppegrell \& B. Colombi (Eds.), Developing advanced literacy in first and second languages (pp. 45-66). Mahwah, NJ: Lawrence Erlbaum Associates.

Chung, T., \& Nation, P. (2003). Technical vocabulary in specialised texts. Reading in a Foreign Language, 15(2). Retrieved from. nflrc.hawaii.edu/Rfl/October 2003/chung/chung.html.

Cowie, A. P. (1999). English dictionaries for foreign learners - A History. Oxford, England: Clarendon Press.

Dicheva, D. (2008). Ontologies and semantic web for e-Learning. In H. H. Adelsberger, P. Kinshuk, J. M. Pawlowski, \& D. Sampson (Eds.), Handbook on information technologies for education and training (2nd ed., pp. 47-65). Berlin: Springer Verlag.

Dovey, T. (2006). What purposes, specifically? Re-thinking purposes and specificity in the context of the 'new vocationalism'. English for Specific Purposes, 25(4), 387-402.

Dudley-Evans, T., \& St. John, M. J. (1998). Developments in English for specific purposes. England: Cambridge University Press.

Fernândez, T., \& Peters, P. (2009). Transdisciplinary approaches to ESP for graduate students in Architecture. In V. Bhatia, W. Cheng, B. Du-Babcock, \& J. Lung (Eds.), Language for professional communication: Research, practice and training (pp. 258-269). Asia-Pacific LSP and Professional Communication Association, and Hong Kong Polytechnic University: Hong Kong, City University of Hong Kong.

Fernández, T., Flórez de la Colina, M. A., \& Peters, P. (2009). Terminology and terminography for architecture and building construction. Terminology, 15(1), $10-36$.

Fernández, T., \& Faber, P. (2011). The representation of multidimensionality in a bilingualized English-Spanish thesaurus for learners in architecture and building construction. International Journal of Lexicography, 24(2), 198-225.

Fuertes-Olivera, P. A., \& Arribas-Bano, A. (2008). Pedagogical specialized lexicography. Amsterdam: John Benjamins.

Fuertes-Olivera, P. A. (Ed.). (2010). Specialised dictionaries for learners. Berlin: De Gruyter.

Halliday, M. (1988). On the language of physical sciences. In M. Ghadessy (Ed.), Registers of written English: Situational factors and linguistic features (pp. 162-178). London: Pinter.

Herbst, T., \& Stein, G. (1987). Dictionary-using skills: A plea for a new orientation in language teaching. In A. P. Cowie (Ed.), The dictionary and the language learner (pp. 115-127). Tubingen, Germany: Niemeyer.

Hyland, K. (2002). Specificity revisited: How far should we go now? English for Specific Purposes, 21, 385-395.

Kittredge, R., \& Lehrberger, J. (1982). Sublanguage: Studies of language in restricted semantic domains. Berlin: Walter de Gruyter. 
Landau, S. (2001). Dictionaries: The art and craft of lexicography (2nd ed.). England: Cambridge University Press.

Lew, R. (2002). Questionnaires in dictionary use research: A reexamination. In A. Braasch \& C. Povlsen (Eds.). Proceedings of the tenth EURALEX international congress, EURALEX 2002, Copenhagen (Vol. 1, pp. 267-271). Copenhagen: Copenhagen University, Center for Sprogteknologi.

Lew, R. (2004). How do Polish learners of English rate bilingual and monolingual dictionaries? In G. Williams \& S. Vessier (Eds.). Proceedings of the eleventh EURALEX international congress, Lorient, France (Vol. 2, pp. 697-706). Lorient, France: Université De Bretagne Sud.

Lew, R. (2011). User studies: Opportunities and limitations. In K. Akasu \& S. Uchida (Eds.), ASIALEX2011 Proceedings, Lexicography: Theoretical and practical perspectives (pp. 7-16). Kyoto, Japan: Asian Association for Lexicography.

Lew, R., \& Galas, K. (2008). Can dictionary skills be taught? The effectiveness of lexicographic training for primary-school-level Polish learners of English. In E. Bernal \& J. DeCesaris (Eds.), Proceedings of the XIII EURALEX international congress (pp. 1273-1285). Barcelona, Spain: Universitat Pompeu Fabra.

Northcott, J., \& Brown, G. (2006). Legal translator training: partnership between teachers of English for legal purposes and legal specialists. English for Specific Purposes, 25. 385-375.

Nuttall, C. (1982). Teaching reading skills in a foreign language. London: Heinemann.

Pearson, J. (1998). Terms in context. Amsterdam: John Benjamins.

Peters, P., Tent, J., \& Fernández, T. (2006). Critical lexicography. In E. Corino, C. Marello \& C Onesti (Eds.), Proceedings of XII Euralex international congress, Turin (Vol. 1, pp. 561-565). Turin, Italy: University of Turin.

Peters, P., Jones, A., Smith, A., Winchester-Seeto, T., Middledorp, J., \& Petocz, P. (2008). TermFinder: Creating online termbanks of technical terms for early university study. Journal of Applied Linguistics, 3(2), 219-248.

Pimentel, J., L'Homme, M.-C., \& Laneville, M. E. (2010). General and specialized lexical resources: A study on the potential to entich formal lexicons. International Journal of Lexicography, 25(2), 152-190.

Read, J., \& Ambrose, M. (1999). Towards a multilingual dictionary of academic words. Lexicos, 9, 172-187.

Rogers, M. (2007). Lexical chains in technical translation: A case study in indeterminacy. In B. A. Antia (Ed.), Indeterminacy in terminology and ESP (pp. 15-35). Amsterdam: John Benjamins.

Tarp, S. (2009). Reflections on lexicographical user research. Lexicos, 19, 275-296.

Temmerman, R. (2000). Towards new ways of terminology description. Amsterdam: John Benjamins.

Tono, Y. (2011). Application of eye-tracking in EFL learners dictionary lookup process research. International Journal of Lexicography, 24(1), 124-153.

Tsakona, V. (2007). Bilingualisation in practice: Terminological issues in bilingualising a specialised glossary. International Journal of Lexicography, 20(2), $1-27$.

Warsch, W. (2005). Power to the learner: An approach towards pedagogically-oriented bilingual dictionaries. Kernerman Dictionary News, No. 13. Retrieved from. Www.kdictionaries.com.

Welker, H. A. (2010). Dictionary use: A general survey of empirical studies. Retrieved from. http://let.unb.br/hawelker/.

Dictionaries referred to within the text

Alcaráz, E., Hughes, B., \& Campos Pardillos, M. A. (1999). Diccionario de têrminos de marketing. Inglés-Español, Spanish-English. Barcelona, Spain: Ariel.

Alcarăz, E., \& Hughes, B. (2008). Diccionario de términos económicos, financieros y comerciales. Barcelona, Spain: Ariel.

Collins COBUILD Advanced learners dictionary (4th ed. 2003). London: Harper Collins.

Collins Robert French dictionary (9th ed. 2009). London: Harper Collins.

Diccionario politécnico de las lenguas española e inglesa (2009). Madrid: Diaz de Santos.

Dictionary of architecture and construction (3rd ed. 2006). New York, NY: McGraw-Hill.

El diccionario Inglés-Español de contabilidad (2012). Recepción, Traducción, Conocimiento, Traducción de Frases y Expresiones. Retrieved from. http:// lemma.com/dictionary/special/center-for-leksikografi/accounting/.

Harper Collins Spanish-English/English Spanish dictionary (2000). Harper Resource.

Longman dictionary of contemporary English: Chinese edition (2004). London: Longman.

Oxford advanced learners English-Chinese dictionary (2004). Oxford University Press.

Penguin Dictionary of Building (2004). Harmondsworth, England: Penguin Reference. 